This item was submitted to Loughborough's Research Repository by the author.

Items in Figshare are protected by copyright, with all rights reserved, unless otherwise indicated.

\title{
Sapper, Hodder \& Stoughton, and the popular literature of the Great War
}

PLEASE CITE THE PUBLISHED VERSION

http://dx.doi.org/10.1353/bh.2011.0011

PUBLISHER

(c) 2011 The Society for the History of Authorship, Reading \& Publishing

VERSION

VoR (Version of Record)

\section{PUBLISHER STATEMENT}

This work is made available according to the conditions of the Creative Commons Attribution-NonCommercialNoDerivatives 4.0 International (CC BY-NC-ND 4.0) licence. Full details of this licence are available at: https://creativecommons.org/licenses/by-nc-nd/4.0/

\section{LICENCE}

CC BY-NC-ND 4.0

\section{REPOSITORY RECORD}

Jaillant, Lise. 2019. "Sapper, Hodder \& Stoughton, and the Popular Literature of the Great War". figshare. https://hdl.handle.net/2134/20553. 


\section{SAPper, Hodder \& Stoughton, AND THE Popular Literature of THE GREAT WAR}

Lise Jaillant

The late I920s saw a boom in so-called disillusioned narratives that focused on the most horrific aspects of the First World War. ${ }^{\mathrm{I}}$ This publishing trend, sparked by the international success of Eric Maria Remarque's All Quiet on the Western Front, provoked a mixed reaction. Many reviewers saw the antiwar narratives as pacifist propaganda, untruthful to the war they had fought and won. ${ }^{2}$ Herman Cyril McNeile shared this distrust of the debunking war books. In the preface of the I930 reprint of his war stories, he wrote: "It is the fashion now . . to speak of the horrors of war; to form societies for the abolition of soldiers; generally, in fact, to say 'Never again." "' Written during the conflict, the stories were first published in the Daily Mail under the penname of Sapper-a reference to McNeile's battalion, the Royal Engineers. Like Siegfried Sassoon and Robert Graves, McNeile was a former public schoolboy and a subaltern officer. Unlike Sassoon and Graves, McNeile had been trained as a professional soldier (he joined the army in 1907 and retired in 1919). ${ }^{4}$ Whereas his account of the war is realistic, to the point of being shocking to some contemporary readers, he never came to share the disenchanted framework so common in the late I920s. Fighting was a duty, and it was better to laugh at it than to dwell on its sinister aspects. Or to be more precise, the horrific descriptions, if part of a truthful testimony on the war, had to go hand in hand with more cheerful aspects. The comradeship and the excitement of an upcoming battle made war bearable, even enjoyable. After Hodder \& Stoughton published five collections entitled Sergeant Michael Cassidy (I9I5), The Lieutenant and Others (I9I5), Men, Women and Guns (I9I6), No Man's Land (I9I7), and The Human Touch (I9I8), Sapper went on to write detective stories and thrillers. His most famous character, Hugh "Bulldog" Drummond, was first introduced as a demobilized officer, "finding peace incredibly tedious" 
and longing for adventure. ${ }^{5}$ His protagonist can be seen as a brutalized exofficer whose thirst for excitement is also an attempt to reenact the war. Following the success of the novel in 1920 , Sapper created a whole series of Bulldog Drummond stories, which became best sellers in the popular Yellow Jacket series. Although these thrillers are still in print today, Sapper has been largely forgotten.

The few critics who studied Sapper after 1945 often dismissed him as a fascist, a propagandist, and a second-rate writer of improbable fiction. More recently, as "nondisillusioned" war writings started to attract some critical attention, ${ }^{6}$ Sapper has been perceived as a writer who is worth studying not for the aesthetic merit of his fiction but because his popularity reflected contemporary attitudes toward the war. This unflattering reputation is at odds with the way Sapper was seen at the start of his career. Why has Sapper, a writer hailed as a literary genius by some his contemporaries, disappeared from the canon of war writings? This article argues that the way Hodder \& Stoughton marketed Sapper's best-selling short stories and novels from I9I 5 to I930 later contributed to his disappearance from the canon. My study of dust jackets and advertising strategy suggests that Hodder \& Stoughton sold Sapper's stories as part of what I call a "war writing brand." Like Ian Hay and John Buchan, Sapper combined horror and laughter in a heroic and justified narrative. Furthermore, Hodder \& Stoughton presented the Bulldog Drummond series as exciting thrillers rather than as stories informed by the war, and thus dissociated Sapper from the conflict. Not only did this marketing strategy shape the way Sapper was perceived in the interwar period, it has also influenced critics to this day. This article aims to reposition Sapper in the literary field of his time, rather than judging his fiction from our own standards of "good" war writings. It also hopes to illuminate our understanding of canon making by examining the largely ignored role that publishers play in shaping the short- and long-term reputation of a writer.

From the I950s to the I970s, when the canon of Great War writings was being created and disseminated, ${ }^{7}$ Sapper was mostly perceived as a thriller writer with fascist sympathies. In Clubland Heroes (I953), Richard Usborne wrote that Drummond's team of ex-officers "was carrying the Führer-principle from the school playing-field to St. James's Square." For Usborne, Sapper was guilty of beating the "nationalistic drum," overdoing pathos, and failing to create convincing female characters. ${ }^{8}$ These criticisms have been extremely influential in shaping Sapper's image. ${ }^{9}$ By the time Michael Denning's book on the British spy thriller was published in 1987 , it had become 
almost a cliché to argue that Sapper's "fascist aesthetic" "heroizes brutality." го Until the late I 980 s, then, the secondary literature on Sapper focused mainly on his crime fiction, ignoring his stories written during the war.

From the I990s, as the canon of Great War literature expanded to include women and popular writers, Sapper's war stories became more visible. In his I990 study of English war writings, John Onions presented Sapper as "an uncomplicated propagandist, revelling in enemy atrocity story and extolling British fair play." II An important turn occurred in I99I with the publication of Samuel Hynes's A War Imagined: The First World War and English Culture. ${ }^{\mathrm{I} 2}$ For Hynes, the Great War had become a myth whose keywords were futility, mud, and death. In an effort to move beyond the few canonical poets, Hynes included popular writers such as Sapper, Ian Hay, Rudyard Kipling, and H. G. Wells. However, A War Imagined mostly concentrated on disillusioned war writings and offered a rather distorted view of the ways the war was interpreted in the I920s and I930s. The domination of these bitter accounts of the war has been questioned by military historians such as Hugh Cecil, who has argued that "book by book, the British public, over a thirty-year period ... seem to have preferred the patriotic to the disenchanted type of war books." "з

Other scholars have continued to examine the popular literature of the war. In Warrior Nation, Michael Paris shows that children's fiction published in book form and juvenile periodicals during the interwar period was dominated by a heroic and purposeful vision of war. ${ }^{14}$ While Paris interprets these stories as propaganda, Jessica Meyer rightly points out that "nondisillusioned" narratives are as valid as the modern view of a futile war. Meyer also notes that the Bulldog Drummond thrillers form a "narrative continuum" with the war stories. ${ }^{15}$ Influenced by Rosa Maria Bracco's work on war fiction, ${ }^{16}$ Meyer views Sapper as a "middlebrow" writer with a highly conservative and formulaic social message: "Sapper's work has little aesthetic merit, being stylised, clichéd and often repetitive; however, his fiction sold extremely well both during and after the war." ${ }^{17}$

But if Sapper's fiction was so bad, why did so many people buy it? Meyer implies that works of popular or middlebrow writers are interesting only as mirrors of contemporary thoughts and perceptions, while canonical war writings have obvious aesthetic merit. In fact, scholars continue to associate the "good" writing of canonical writers with their "good" pacifist message, while the "bad" writing of popular writers is linked to their view of the war as an adventure. Meyer thus argues that the heroic "understanding of war was, after all, to influence another generation of young men called upon to 
submerge self in the defense of their nation in war." ${ }^{18}$ This image of legions of young soldiers determined to sacrifice for their country during the Second World War echoes the myth of the previous war. As Dan Todman suggests, the numerous studies that have aimed to deconstruct this myth and to present the First World War as "a great forgotten victory" have not "made the slightest difference to what most people actually believe": "the same basic understanding of the war as tragedy and disaster still pervades British culture." ${ }^{19}$

When analyzing a war writer such as Sapper, it is important to avoid retrospective judgments. Sapper was not seen as "middlebrow" immediately after the war. ${ }^{20}$ His fiction did convey a conservative social message, but was marketed as light and entertaining (a characteristic of "lowbrow" and popular writers). In fact, Sapper's image as a witness of war did not survive his inclusion in the Yellow Jacket series.

I now trace Sapper's journey from war writer to thriller writer, from the beginning of his career in I9I 5 to the last edition of short stories in I930. Between I9I5 and I9I8, Hodder \& Stoughton released five collections of Sapper's stories, many of which had first appeared in the Daily Mail. ${ }^{2 \mathrm{I}}$ From I926 to I930, four collections of war stories were published: Shorty Bill, Jim Brent, John Walters, and Sapper's War Stories, none of which included any new stories. For instance, John Walters (I927) is an anthology of texts first published as The Lieutenant and Others, The Human Touch, and No Man's Land.

From the start of his writing career, Sapper was on the wrong side of posterity. His association with the Daily Mail placed him outside the most prestigious intellectual spheres. By publishing his stories in a popular newspaper, Sapper was sure to be read by a large public of lower-middle-class readers, therefore establishing himself as a commercial writer. Indeed, his first war story appeared in the Daily Mail on January I3, I9I 5, with the following introduction: "Nothing fresher and more vivid has been produced by any young professional writer than these Reminiscences of Sergeant Michael Cassidy which we have received from a subaltern in the Royal Engineers." ${ }^{2}$ Here an opposition is drawn between the front line and the home front, between soldier-writers who can testify on the reality of modern warfare and "professional writers" who have not necessarily seen combat.

This collaboration with the Daily Mail was undoubtedly an exceptional opportunity for an unknown writer. The Mail marketed Sapper as the true voice of frontline fighters. His stories were generally featured on page 4, where they could hardly be missed by any reader. Even the irregularity of publication pointed to Sapper's position as a soldier. Unlike professional 
writers, his writing time was conditioned to his role in the war. For example, six days separated the publication of the first and second Cassidy stories; but readers had to wait fifteen days between the third and fourth episodes. And in I9I 5, the Daily Mail circulation peaked at I, I05,2I4-an impressive readership for a twenty-seven-year-old beginner. ${ }^{23}$

But the association with the Mail also carried risks to his literary reputation. Not only could Sapper be dismissed as a lowbrow writer, he could also be smeared by the reputation of the Daily Mail as a propaganda newspaper. Lord Northcliffe, the owner of the Mail, was very close to influential political figures of his time and even accepted the post of director of propaganda in enemy countries in February I9I $8 .^{24}$ Sapper's mix of horror and humor appealed to Northcliffe, who apparently suggested that he should be released from the army to work as a war correspondent. ${ }^{25}$ But it also fitted perfectly with the editorial line of Hodder \& Stoughton, a publishing house that understood the market potential of the war. As in the case of the Daily Mail, Sapper's lifelong relationship with Hodder \& Stoughton enabled him to become a household name, but it later pigeonholed him as a prowar writer.

No other publishing house was more closely associated with propaganda than Hodder \& Stoughton. The firm's director, Ernest Hodder-Williams, and its editor and literary adviser, Sir William Robertson Nicoll, "had close personal ties to the corridors of power," as Jane Potter notes. ${ }^{26}$ The War Propaganda Bureau, better known as Wellington House, and the Department of Information, which replaced it in I9 I 7, used commercial publishers to disseminate texts so that their government origins could not be traced. ${ }^{27}$ The Schedule of Wellington House Literature, kept at the Imperial War Museum, shows that Hodder \& Stoughton published more than I30 pamphlets and books for the bureau, a number unmatched by any other publishers. These government-sponsored works ranged from atrocity tales-with such titles as Pan Germanic Crime and When Blood Is Their Argument-to books explaining the war to children..$^{28}$ Moreover, The Schedule of Wellington House Literature shows that the Doran Company, a New York imprint, published British propaganda for the American market. It is significant that Doran began publishing Sapper in I9I6 in the United States and remained his American publisher until his death in 1937.29

Not only was Sapper associated with a propaganda newspaper and published by two imprints with close links to Wellington House, his own literary agency, A. P. Watt \& Son, also acted as an intermediary between the government and commercial publishers during the war. ${ }^{3 \circ}$ Indeed, Alexander Strahan Watt was present at the second conference organized by the Propa- 
ganda Bureau on September 7, I9I4. Sir William Robertson Nicoll and a representative of the Daily Mail were also at the meeting. ${ }^{31}$ Until the end of the war, the Watt firm carried out negotiations with the publishers on Wellington House's behalf. Thus when Sapper was starting his literary career, he found himself in a web of literary actors who shared a similar view of the war and a strong involvement in the propaganda effort.

Although Sapper's war stories were not sponsored by the government, he belonged to the same networks as John Buchan and Ian Hay-agented by Watt and published by Hodder \& Stoughton. ${ }^{32}$ Both Buchan and Hay wrote on the war in an entertaining way, and both had close links with propaganda. ${ }^{33}$ Indeed, Sapper, Buchan, Hay, and others were grouped together and advertised as a successful "war writing brand." For instance, the last page of Sapper's No Man's Land advertises Captain Eustace Ainsworth's 2nd Lieutenant Billie Impett and His Orderly (I9I7): "Captain Eustace Ainsworth is a born story-teller; he has style, a keen, observant eye, and a great sense of humor. And he knows what fighting is, for he has fought himself."

As the star of this "war writing brand," Sapper benefited from major advertising campaigns. The Hodder \& Stoughton Profit and Loss Ledger shows a steady increase in the advertising budget for Sapper's war stories. ${ }^{34}$ A total of $£_{2}$ I was spent for the promotion of Sergeant Michael Cassidy, $£ 65$ for The Lieutenant and Others, $£_{\mathrm{I}} 87$ for Men, Women, and Guns, and $£_{347}$ for No Man's Land. ${ }^{35}$ Advertisements in the Times make clear that Sapper was increasingly promoted as a best-selling writer. Whereas Sergeant Michael Cassidy received a small mention at the bottom of a list announcing Hodder \& Stoughton's new releases in I9I 5, Men, Women, and Guns had risen to the first place of a similar list in I9I6 (Figure I). The last collection of Sapper's stories to be published during the war, The Human Touch, was less advertised, with a total of $£_{243}$ spent in I9I9 and I920, probably reflecting weariness with war stories after the Armistice.

Whether one believes that advertising creates best sellers or that big sales encourage publishers to increase their advertising budgets, Sapper's war stories sold extremely well during the war. Between I9I6 and I9I8, approximately I 35,000 copies of Sergeant Cassidy and I39,000 copies of The Lieutenant and Others were sold. Men, Women and Guns sold around I 3 I, 500 copies from I 9 I 7 to $1926 .{ }^{6}$ This success is all the more impressive if we take into account the difficult wartime context. Fewer titles were published: $\mathrm{I} 2,379$ in $\mathrm{I}_{9} \mathrm{I} 3$, but only $8, \mathrm{I} 3 \mathrm{I}$ in $\mathrm{I}_{9} \mathrm{I}_{7} .{ }^{37}$ Furthermore, paper was rationed, which created a "constant business concern" for publisher Ernest Hodder-Williams. ${ }^{38}$ 


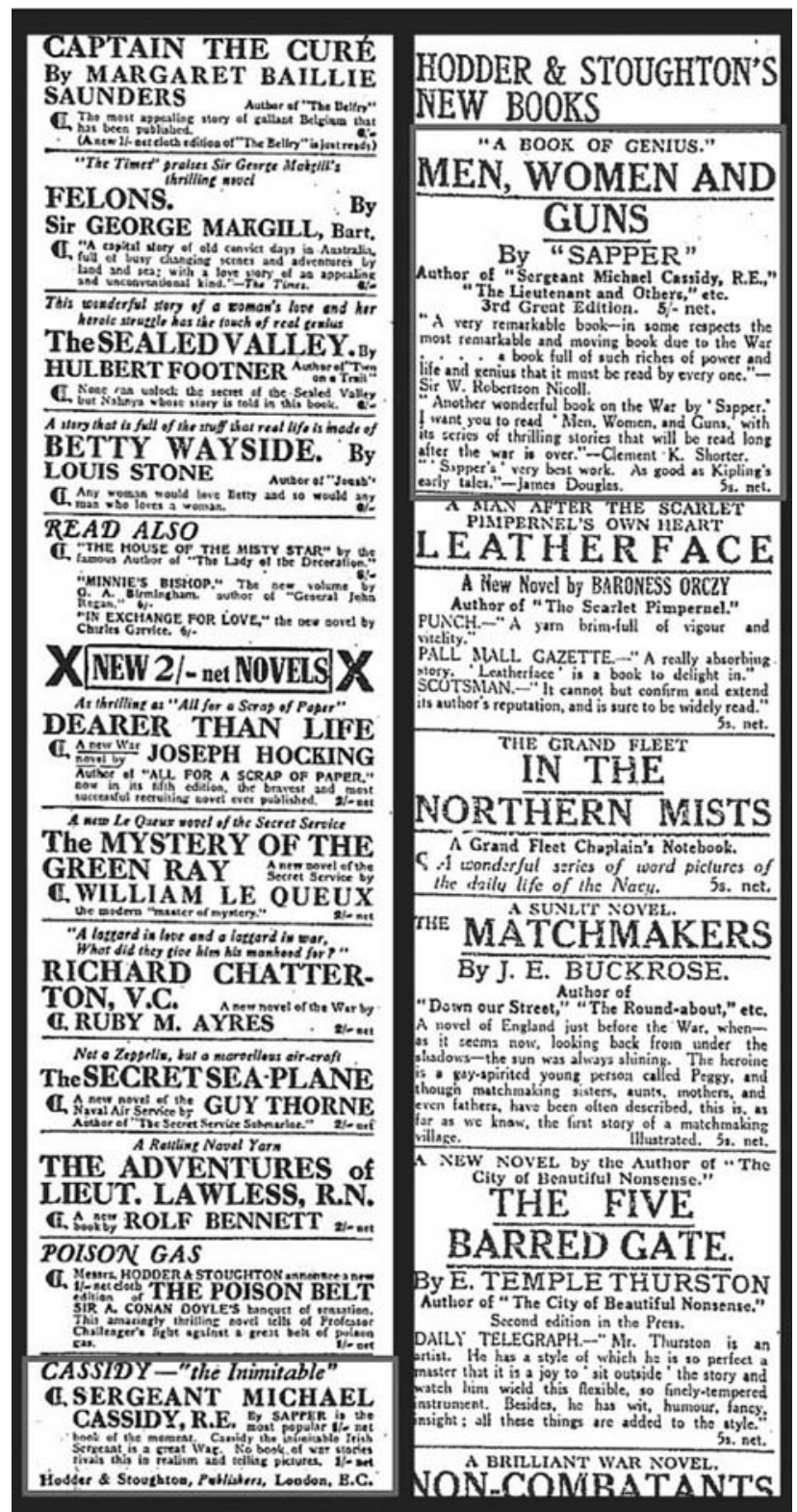

Figure I. Advertisements for Sergeant Michael Cassidy (left) and Men, Women, and Guns (right) published in the Times (July 23, I9I 5, and October 6, I916). On the left is also advertised Ruby M. Ayres's Richard Chatterton, V.C. with the following description: "A laggard in love and a laggard in war, what did they give him his manhood for?" 
Figure 2 juxtaposes the sales figures for all the collections of Sapper's war stories and the advertising budget. It shows that advertising initially followed huge sales more than it initiated them. In other words, Sergeant Michael Cassidy was already selling well before an increase in advertising was decided. This rapid success was undoubtedly helped by the Daily Mail: not only did Sergeant Michael Cassidy receive a positive review on the day it was published, ${ }^{39}$ it was also regularly promoted in the Mail, with reminders that the book could "be had at every railway bookstall." ${ }^{\circ}$ Moreover, Sapper's stories were sold at only one shilling. The Publishers' Circular noted "the wonderful sale some of the shilling books are having," and advised booksellers to stock Sapper's war stories. ${ }^{4 \mathrm{I}}$ Finally, the attractive dust jackets also contributed to Sapper's success (Figure 3). ${ }^{42}$

Sapper's narratives were celebrated as the genuine reflection of the modern war, far from sentimental and patriotic tales. Reviewing Men, Women, and Guns for the Times Literary Supplement (TLS) in 1916, Francis Henry Gribble compared the author to a "nonchalant" "British sportsman": "the sportsman-like manner is just as bracing as the heroic manner, and most of us find it more readable." ${ }^{33}$ The contrast between Sapper's stories and heroic narratives is also emphasized in a I9I 5 review of Sergeant Michael Cassidy in the Daily Mail, which contrasted the detachment of Sapper's fiction with the "sentimentality" of another war book written by Philip Gibbs. ${ }^{44}$ Most important, reviewers described Sapper as a major literary figure. As Gribble noted in the TLS: "Sapper has been successful in previous volumes of war stories. ... When the time comes for picking out the writers whose war fiction has permanent value, his claim to be included in the list will call for serious examination." ${ }_{45}$ American newspapers also conveyed the impression that Sapper was the new Kipling. Reviewing Michael Cassidy in I916, the New York Times argued that Sapper's "sketches of scenes and incidents and men under the roaring guns and bursting shells of the French war zone reveal a knowledge, a skill and a talent for other matters than the science of war." ${ }^{6}$ For the Atlanta Constitution, Sapper's Men, Women, and Guns was "a book of truth and reality by a British officer made an outstanding literary figure by the sheer force of war." ${ }^{47}$ A I9I7 review of No Man's Land in the same newspaper reminded readers that Sapper "has been called the foremost literary genius of the British army." ${ }_{48}^{8}$ The realism of No Man's Land was also praised in the New York Times: "It will bring to each reader an awakening stab of realization of what this individual war is to the individual soldier." ${ }^{49}$ Sapper's war stories therefore combined high sales with enthusiastic reviews in distinguished newspapers-a rare achievement for a writer who had started his career in the Daily Mail. 


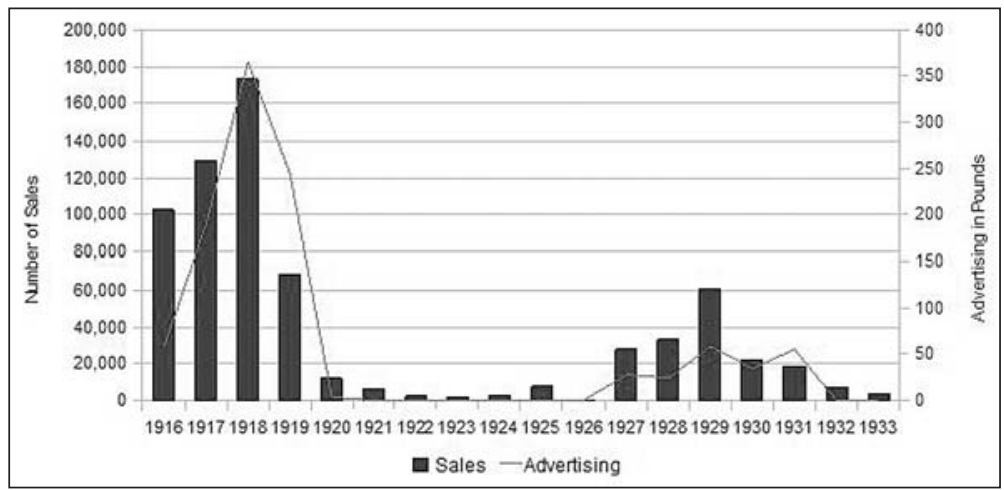

Figure 2. Sales and advertising for Sapper's war stories, I9I6-I933.

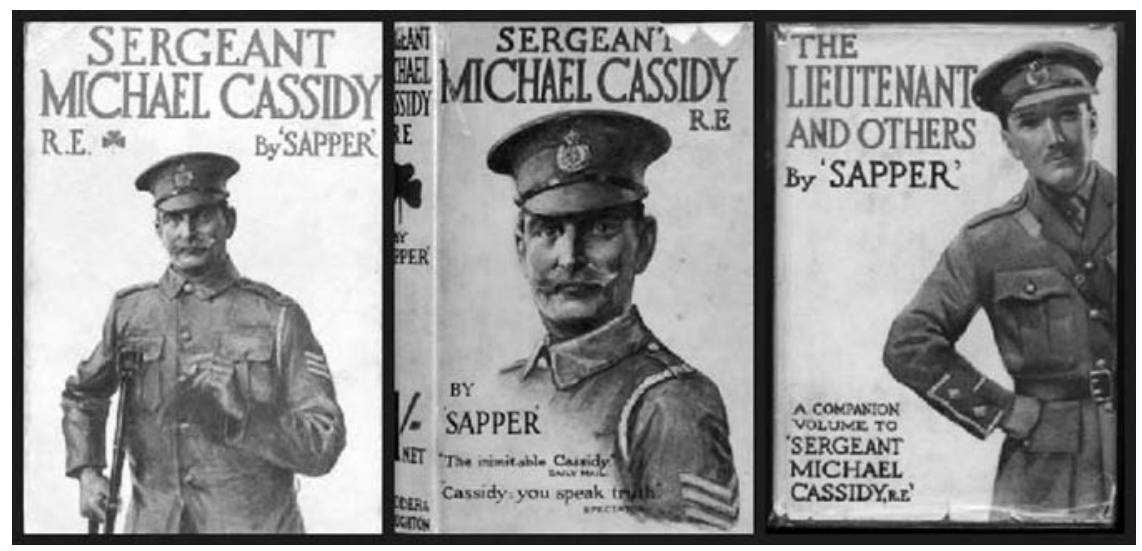

Figure 3. Dust jackets of Sergeant Michael Cassidy and The Lieutenant and Others (Hodder \& Stoughton, I9 I 5). The left picture is probably a first paperback edition. The central picture is from the hardback edition later that year, and shows Cassidy without a crutch.

When the collections of short stories were reprinted under different titles in the late I920s, they were not as successful as during the war. Nonetheless, Sapper's three collections of reprinted short stories (Shorty Bill, Jim Brent, and John Walters) sold a total of 60,000 copies in 1929 alone, despite a meager advertising budget. Even at the height of the disillusioned war memoir boom, Sapper's war stories continued to appeal to a relatively large public. In I930, Hodder \& Stoughton issued another reprint entitled Sapper's War Stories. Unlike the previous editions, this last collection of war writings 
sold only 19,257 copies between I930 and I939. How can we account for this relative failure? It is interesting to compare the marketing of Shorty Bill and John Walters, on the one hand, and Sapper's War Stories, on the other hand. Both the dust jackets and the price tag seem to point to different commercial strategies. As Michael Birch has argued, "increasing sophistication in colour printing" meant that by the I920s, dust wrappers had become a major "selling device." $5^{\circ}$ In I923, Hodder \& Stoughton introduced the Yellow Jackets series, mostly sold at two shillings in a bold yellow wrapper. Not only was the front cover designed, the spine also repeated the slogan that identified each writer. For instance, "Thanks the Powers that be for Sapper" was clearly visible on the spine of Shorty Bill and John Walters. This slogan, featured on advertisements and the book itself, contributed to "product identification." ${ }^{\mathrm{I}}$ Both covers also presented Sapper as a best-selling writer: "From the books that made Sapper famous in the war" and "War stories by the author of Bulldog Drummond." Additionally, the cover picture showed a benevolent-looking warrior during moments of relaxation. No mud or rats here: just an ordinary soldier, smoking and seemingly enjoying himself (Figure 4). Long after the conflict, Hodder \& Stoughton was again selling its

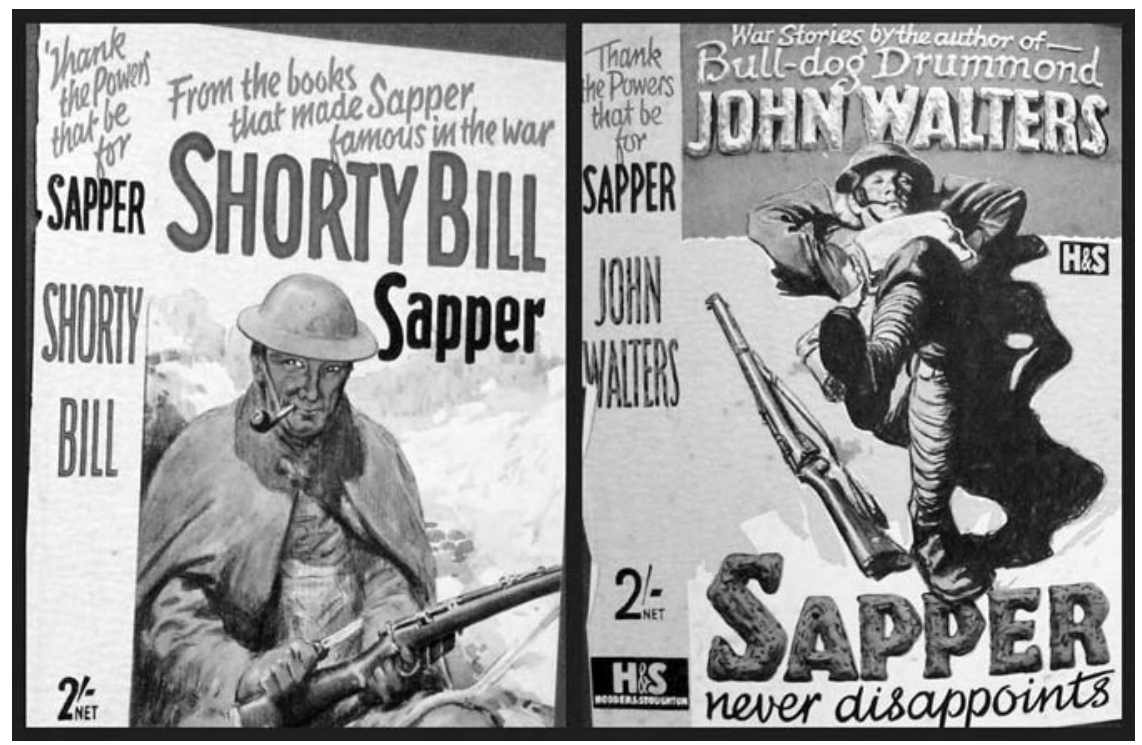

Figure 4. Dust jackets of Shorty Bill and John Walters (Hodder \& Stoughton, I930s; first eds. I926 and I927). Princeton University Library. 
successful "war writing brand," with attractive dust jackets, cheap editions, and product identification.

The I930 edition of Sapper's War Stories seems to highlight a different commercial strategy. Contrasting with the cheerful soldiers of Shorty Bill and John Walters, the dust jacket of War Stories pictures bright red poppies against a background of barbed wire (Figure 5). Today, these symbols of sacrifice and mourning have become so omnipresent that no exhibition on the First World War would be complete without them. Moreover, the cover of the I930 edition did not refer to Sapper as a successful thriller writer, nor

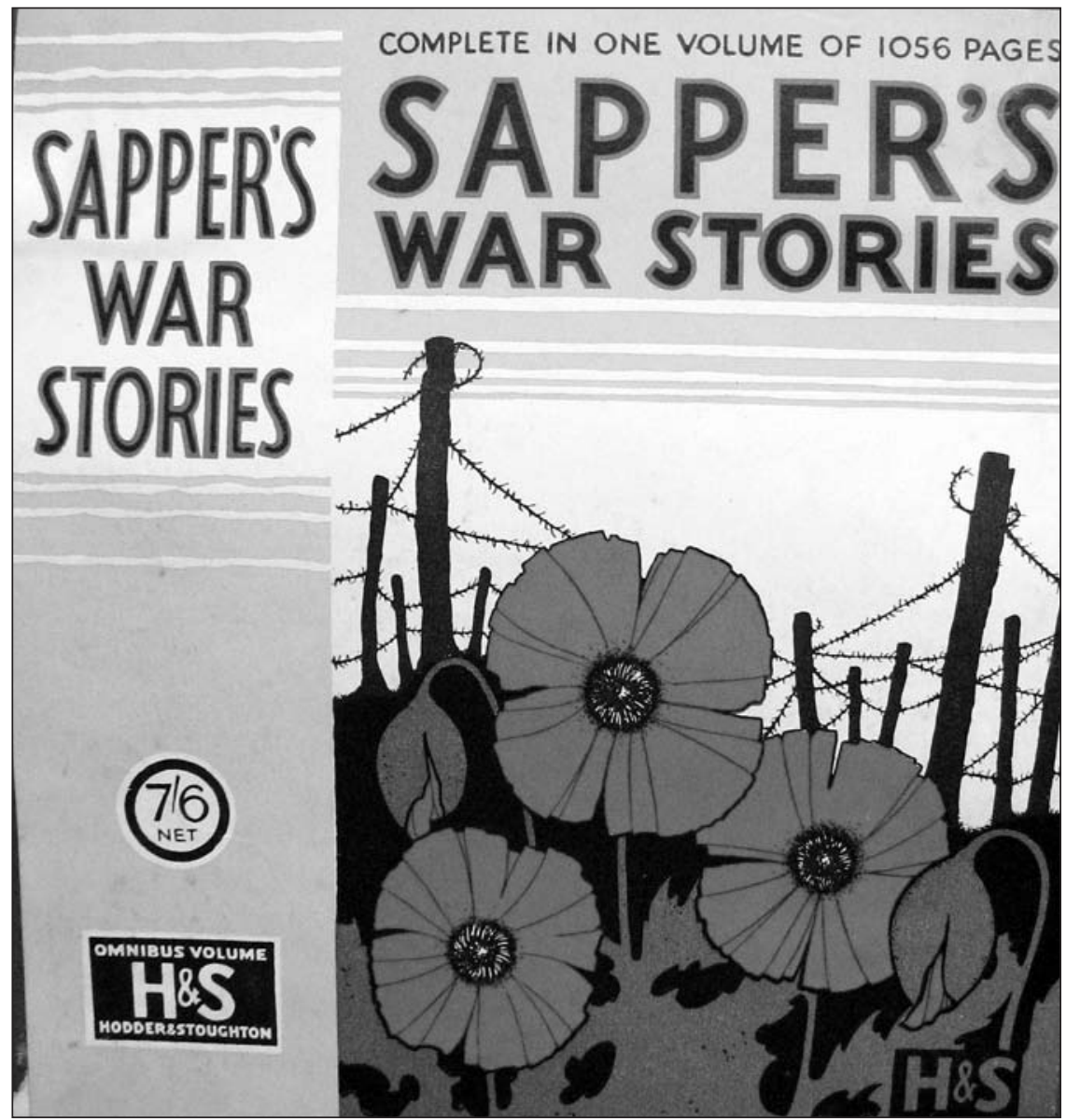

Figure 5. Dust jacket of Sapper's War Stories (Hodder \& Stoughton, I930).

Princeton University Library. 
did it feature any slogan. Finally, the price tag of $7 \mathrm{~s} 6 \mathrm{~d}$ was undoubtedly expensive for reprinted stories. The marketing of the book was in sharp contrast with the preface and the tone of the short stories. Instead of a memorialization dominated by mourning, Sapper remembered the war as a purposeful activity, even if the benefits of increased social solidarity had been lost. His war was not bitter, only the aftermath was (WS 9). In other words, Sapper's stories were far from the tales of endless mourning and disappointment characteristic of the late I920s.

The success of Sapper's stories, from I9I 5 to I930, cannot be explained solely by cunning marketing and promotion. This fiction sold extremely well because the account of the war was perceived as realistic, fitted in a set of expectations, and in turn contributed to shaping the interpretation of the conflict. Many scholars have noted the realism of Sapper's war stories, ${ }^{52}$ but nobody has yet examined the relationship between the stories published in the Daily Mail and the versions collected in book form. Yet the differences between the versions highlight the constraints Sapper probably felt when writing for the Daily Mail.

The format of Sapper's short stories had to satisfy the newspaper's requirements. Sergeant Michael Cassidy was divided into very short chapters that could be read independently of each other. It is interesting to compare the version printed in the Mail in I9I 5 with the one published by Hodder \& Stoughton later the same year. The order and the tone of certain episodes have been significantly changed in the Hodder version. For instance, in an episode entitled "The Guards Who Never Budge," Cassidy tells the narrator of an "ugly sight" he encountered at dawn in the trenches. In the Daily Mail, the revulsion is explicit, but Cassidy shows no pity for the German soldier "dead on the wire":

He was lying on the apron of the wire, and his head was twisted and he was grinning....

"Ah! For the Holy Mother's sake turn your face away," I muttered, for my nerves were a bit upset and I could not take my eyes from that grin. ${ }^{53}$

In contrast, the version published by Hodder \& Stoughton is much more compassionate:

I have a wife, I said to him [another soldier], a wife and four kiddies in Ballygoyle, and it's thinking I am that that man there may have the same. ${ }^{54}$ 
It is hardly surprising that any compassion for the Germans should have been taboo in the Daily Mail, a newspaper that regularly featured atrocity stories perpetrated by the "Huns." When editing his story for publication, Sapper could offer a more subtle account of the scene, charged with horror and empathy for the war victims.

In the collection that followed Sergeant Michael Cassidy, Sapper continued to present himself as a witness of the Great War, and his stories as truthful and informative. In the preface of The Lieutenant and Others, he introduced with a typically ironic tone the setting of his sketches, the "salient of Ypres": "There may be some who will recognise-not, I trust, without a throb of pleasure-Hooge, Frizenburg, the Meningate, and other health resorts of that delectable neighbourhood." 55 Indeed, McNeile had seen combat at Ypres, where he was gassed in the second battle. ${ }^{6}$ His stories were not only aimed to fellow soldiers, who would recognize the desolated setting, ${ }^{57}$ but also to civilians who could expect to gain a better understanding of the war.

This ambition to be a witness can also be seen in the directness of certain stories, written shortly after the events in question. Thus, "The End of 'Wipers" was published in the Daily Mail dated May 20, I9 I 5, and described "a city of the dead" where soldiers with "yellow-green" faces struggle to survive..$^{8}$ Knowing that the second battle of Ypres was still ongoing at the time of the publication, Sapper's account of gas attacks has the quality of a diary, where "the act of writing almost coincides with the events and experiences described." ${ }_{59}$ When "The End of "Wipers" was collected in The Lieutenant and Others, a subtitle was added-“A Sketch Written during the First Week of May"-emphasizing the immediacy of the account.

Sapper presented himself as a soldier-witness: "The man on the spot knows best," as one character in The Lieutenant maintains ( $\mathrm{LO} 28$ ). The Great War is thus described as radically different from previous conflicts. As Cassidy puts it: "Was I not through the South African War, are you putting this on the same footing at all?" (SMC 99-I00). He portrays the modern battle of material as essentially horrific: "Tis no good pretending that this war is anything but hideous" (SMC I69). The disastrous consequences of modern warfare on the combatant's body and mind are vividly highlighted. Not only can a soldier be stuck in the mud for "four days and four nights" without being helped, he might also face unbearable decisions (SMC IOI). The example of the officer who kills an insubordinate or coward subaltern is regularly featured, although these scenes did not appear in the Daily Mail. Hence, in "The Terrible Danger of Funk," the narrator explains that every officer should be mentally ready to shoot to kill when discipline is at stake 
(SMC I64-I 65). This story seems to have been written especially for the Hodder \& Stoughton edition of Sergeant Michael Cassidy. ${ }^{60}$ Scenes of deliberate firing on one's own troops for disciplinary reasons may have been thought too distressing for a mainstream newspaper. Yet the fact that these sketches appeared in the Hodder \& Stoughton books shows that Sapper did not hesitate to tackle controversial subjects.

The experience of the modern "war machine," in Daniel Pick's words, also meant the disappearance of traditional face-to-face combat. Although some of Sapper's stories feature "man-to-man" fights, these "isolated encounters" are described as "rare." ${ }^{61}$ More frequent is the exposure to massscale death, and the resulting trauma it entails: "To bag a man with a gun is one thing; there is sport-there is an element of one against one, like when the quality goes big game shooting. But to bag twenty men by a mine has not the same feeling at all, even if they are Germans" (SMC I64-165). Here, two conceptions of war are opposed: the chivalric combat between gallant warriors, and the mass murder of modern warfare. The first one is compared to entertainment and sport, a pleasurable activity close to hunting. But weapons of mass destruction are presented as a means of industrialized killing, which leaves the soldier bitter.

These oppositions also inform the descriptions of the enemy. Sapper's stories frequently feature atrocity tales committed by a barbaric antagonist. ${ }^{62}$ Germans are described, on the one hand, as "swine, with the manners of swine," and, on the other, as "brave" and "gallant soldiers." The adjective "brave" is also used to depict a German spy, and even snipers who prey on British soldiers (SMC I6I, II3, 98, I05). This paradoxical respect for and admiration of the enemy, coupled with disgust, will reappear in the Bulldog Drummond series. In a word, Sapper's vision of the war is one of ambiguity. Trench warfare is breathtaking adventure and revolting mass murder. The Germans are horrendous Huns and chivalric warriors. This ambiguity is extended to civilians, portrayed either as a worthy audience willing to understand the real war or as frivolous socialites and cowards. ${ }^{63}$

If Sapper's vision of the war defies simplistic characterizations, the dominant tone remains far from our contemporary memory of meaningless slaughter. Despite its hideous nature, the war is consistently described as a positive experience and a test of manhood. The Lieutenant can thus be analyzed as the coming-of-age story of a rich young man, idle and bored, who is transformed into a selfless leader by the war. ${ }^{64}$ As a regular army soldier, Sapper accepted the military values of honor, discipline, and sacrifice. Under the penname of C. N., he wrote a series of articles for the Times to explain their duties to new officers. These articles, collected as The Making of an 
Officer in I916, insist on the qualities of leadership and selflessness essential to "inspire" subalterns. As in Sergeant Michael Cassidy, the idealization of war is ridiculed: "Those who still look on war as a romance will be sadly disillusioned when they get out there." The opposition between the romantic delusions of many young officers and the realities of modern warfare is pointed out but does not result in a condemnation of war. On the contrary, combat is seen as the tuition of manhood. Only bravery and sacrifice can bring meaning to life. "You have reached the greatest glory of manhoodyou have not lived in vain," concludes the last article. ${ }^{65}$

To understand why Sapper lost his reputation as a "literary genius" so quickly, we need to turn to his first novel, Mufti, published in I9r9. A review in the Bookman (a magazine published by Hodder \& Stoughton) presented Sapper as one of the only war writers gifted enough to survive the falling popularity of war fiction: "The magazine editors and the book publishers knew that the day for such war fiction had passed, and now the only war writers who receive attention are the few who by their craftsmanship and wide human appeal have a likelihood of more than ephemeral fame. Among them is Cyril McNeile, the soldier who writes under the pen-name of 'Sapper." ${ }_{66}^{6} M u f t i$, which tells the story of an infantry captain who falls in love with two women, was perceived as a war book although the central plot takes place in postwar Britain. The satirical magazine Punch pointed out that "the light [Sapper] throws upon life as certain classes lived it during the War is a true and useful light." ${ }^{67}$ Despite these positive reviews, Mufti was a commercial failure. Out of a first printing of 20,000 copies, around I 6,700 had been sold by March I920. Hodder \& Stoughton then liquidated the remaining stock, and by $1922 \mathrm{Mufti}$ was out of print.

This failure might be explained not only by the decreasing appetite for war books, but also by the awkward positioning of $M u f t i$. The cover seems to present the book as a romance, a reference to the sentimental plot (Figure 6). ${ }^{68}$ Yet many reviewers were struck by the violence and realism of certain scenes, in particular the gas attack on the western front and the sinking of a passenger ship in the Irish Sea.

After the failure of Mufti, Sapper did not cease to write about the longterm effects of the war. But he ceased to be marketed as a war writer and became identified as the creator of the Bulldog Drummond series. From I920 to his death in 1937 , Sapper wrote ten novels featuring Bulldog Drummond and his "gang." The subtitle of the first book-The Adventures of a Demobilised Officer Who Found Peace Dull—immediately placed this character under the shadow of war. The following section examines this alternative 


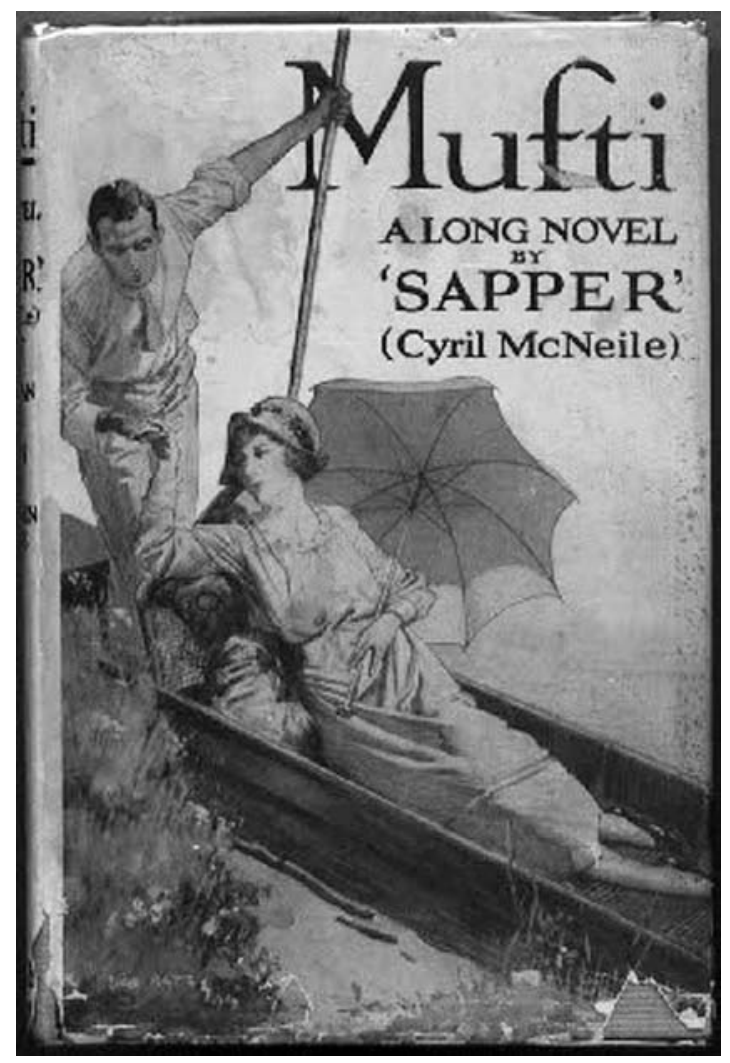

Figure 6. Dust jacket of Mufti by Leo Bates (Hodder \& Stoughton, I9I9).

memory of the Great War, focusing mainly on the first four Bulldog Drummond novels, published between 1920 and 1926: Bull-Dog Drummond, The Black Gang, The Third Round, and The Final Count. These four were grouped together in a 1929 edition, titled Bull-Dog Drummond: His Four Rounds with Carl Peterson, which can be read as a long novel, starting with the first encounter between Drummond and his enemy Carl Peterson, and finishing with the arch criminal's death. These novels were published before the war books controversy divided the memory of the Great War. As Meyer has suggested, these postwar thrillers can be read in continuity with Sapper's war stories, since both treat the war as a trial with manhood at stake.

In a 1922 review of The Black Gang, Hugh Drummond is described as a "child of the war." ${ }^{69}$ Indeed, Drummond's experience in the trenches has shaped his social identity, his skills, and even his physical appearance. But 
to the uninformed, Hugh Drummond is just an idle young man, living a life of leisure. As a gentleman of private income, he does not work and seems to spend his life in clubs, drinking cocktails with his friends, ex-officers like himself. ${ }^{70}$ In other words, Drummond and his social circle can be seen as outcasts who find it difficult to adjust to postwar society. Drummond does not share the same ambitions as his former classmate Sir Bryan Johnstone, the director of criminal investigation at Scotland Yard. Whereas Johnstone obtained "a well-deserved knighthood and a high position in the land" ( $B G$ 223), Drummond aspires to the thrills of combat. The ex-soldier refers to war as a sport or a game, the same metaphors used in Sapper's war stories: "For four years he had played one game where no mistakes were allowed" (BD 76).

To satisfy this aspiration, Drummond and his gang become vigilantes by night. This secret life is structured along military lines, with an undisputed captain and disciplined subalterns. The obedience to the leader is so absolute that it borders on religious devotion. Indeed, Drummond is "worshipped by his men" (BD 65). This ideal of a leader who can convince his men to follow him even if it means certain death was already expressed in The Making of an Officer. Sapper defined a good officer as one who could inspire his troops, especially during dangerous attacks. Drummond recreates that past war experience, when he was an all-mighty leader who controlled his men's lives and deaths.

The circle around Drummond is composed of veterans who speak the language of war. For instance, "Hugh realised that the situation was what in military phraseology might be termed critical" $\left(B D\right.$ 6I), ${ }^{71}$ and the expression "the fog of war" is recurrent $(B G 233,3$ I 6, FC 64I). Drummond and his "gang" fight never-ending war-once against Germans, now against criminals-as a way to fit in a society at peace. As Esther MacCallum-Stewart suggests, Drummond's "characterisation demonstrates ways in which the discontented can find a new place in society, and satisfies the demand for a soldier to remain a hero." 72

If Drummond's admirers consider him a hero, he is certainly not an incarnation of Good. In fact, he can be seen as a soldier brutalized by the war, resembling many characters in Sapper's short stories. Despite his humorous promise to his servant's wife- "I shall only undertake murder in exceptional cases" ( $B D$ I6)-Drummond does not hesitate to kill in the most brutal manner. He is described as a hunter (TR 492) whose skills match the animals he tracks. Like a predator, he is able to move in perfect silence $(B G$ 344). He can break a man's neck with his own hands, a grip he learned from a Japanese instructor and practiced at night in no-man's-land (BD 65). 
Sapper's earlier story "The Death Grip," collected in Men, Women, and Guns, introduced an officer who had been taught to kill with his bare hands. Another wartime anticipation of Drummond as a predator can be found in Shorty Bill, a character who first made an appearance in No Man's Land and The Human Touch: he is a battalion sniping officer who has learned "silent tricks" to kill his prey by surprise. ${ }^{73}$

The war is therefore viewed as a school in brutalization, where one could murder with impunity. But far from presenting this "training" as a fall into bestiality, Sapper characterizes his protagonist as a superior human being, able to kill without emotion. Drummond's senses have been sharpened to near perfection $(B G$ 273). The school of war also taught him to suppress any feelings. Like Peterson, a man who does not betray his emotions, Drummond is indifferent to the pain he inflicts. When he breaks a German's arm, he is not moved by the "scream of pain" (BD I60). Moreover, he does not hesitate to throw his enemy Henry Lakington in a bath of acid and to watch his victim becoming "mad with agony" (BD I85). In The Black Gang, Drummond once again "fight [s] to kill," and inflicts a broken neck and a severed artery on his opponent $(B G 348,383)$. He also ferociously murders a Bolshevik, pinning him to the wall with a bayonet. The body is compared to "a dead butterfly" "fixed in a collection with a pin" (BG 376). A similar comparison can be found in Sergeant Michael Cassidy, with a "Prussian pinned like a beetle in a box" (SMC I I3).

This continuity of images and themes between the short stories and the novels shows that Drummond is a product of the Great War, a conflict of unprecedented scale and brutality. His opponents are compared to animals that deserve no pity. One of the men killed by Drummond is described as "a dreadful-looking specimen, more like an ape than a man" ( $B G$ 383). Although it does not seem to have been condemned, this brutality was certainly noted by contemporary reviewers. For example, a TLS review in I928 observed that Sapper "is so wholehearted in his violence that it is difficult for his villains to survive through more than a volume." ${ }^{74}$ In fact, Drummond's aggressive methods were generally seen as a fair response to a brutalized world.

To a large extent, the world described in the Bulldog Drummond series is still at war. But instead of being fought along national lines, the conflict is between a conspiracy of foreigners on the one side and Drummond's gang on the other side. Carl Peterson speaks four languages fluently and is "completely cosmopolitan" ( $B D$ 7). He is helped in his devilish plans by an army of crooks, among them Bolsheviks and Jews, who are mostly motivated by money under the cover of a revolutionary ideology ( $B G$ 2I3). On the opposite side, Drummond and his friends are archetypes of English gentlemen. 
Even Drummond's nickname, "Bulldog," symbolizes the fierce character of the English.

Samuel Hynes claims that many conservative novels of the I920s feature ex-soldiers defending "an idealized Old England" against "foreigners, Jews, radicals, Irishmen, Bolsheviks, profiteers, and intellectuals." In addition to Bulldog Drummond, Hynes gives the example of John Buchan's The Three Hostages, published by Hodder \& Stoughton in I924: "The 'wars' that are fought in these novels are patriotic, nationalistic wars, which was no doubt one reason for their great popularity." 75 While there is undoubtedly a community of style and values between Sapper and Buchan, it might be argued that the patriotism displayed in the Bulldog Drummond series is a pretense. Drummond is far too individualistic and defiant of authority to be truly patriotic. He does not present his combat as a way to save England, but as the "life of sport" he desires. As a conservative upper-class man, he has a natural disgust of Russian revolutionaries and their supposed Jewish cosmopolitan allies. But that does not make him a nationalistic warrior, ready to put his country's interests before his own.

If he does not primarily defend England's interests, Bulldog Drummond nevertheless fights a dangerous enemy that uses weapons developed during the Great War. The cynical Henry Lakington tells a German villain: "An ingenious invention is gas ... we owe your nation quite a debt of gratitude for the idea" (BD 88). Gas is also employed in The Final Count in order to blind and neutralize Drummond's gang. The illustration in Sovereign Magazine visually reinforced the narrative (see Figure 7 , right picture). Furthermore, in The Black Gang a bomb is thrown at Drummond and two of his associates, killing one of them: "What was left of him adorned a corner" (BG 278). In The Third Round, a professor's lab is blown up, prompting Drummond to remark that "the darned place looks as if it had had a direct hit with a big shell" (TR 453). Once again, the vocabulary finds its roots in the warfare of the trenches. Describing an American victim who has been tortured and poisoned, Drummond compares him to a victim of shell-shock (BD $4 \mathrm{I})$. In The Final Count, the young scientist Robin Gaunt, a gas expert during the war and the inventor of a particularly deadly poison, is taken hostage by the Peterson gang, who then use his weapon of "universal, instantaneous death" against a yacht of millionaires. In a scene reminiscent of the shellings in The Lieutenant, the "rain of death" falls on the boat, instantly killing its occupants (FC 593, 748). Appalled by this brutality, Gaunt falls under the delusion that the world is still at war. Like the officer in Sergeant Michael Cassidy who loses his reason after being shelled (SMC I74), Gaunt is trapped in an eternal present of trauma and violence. 


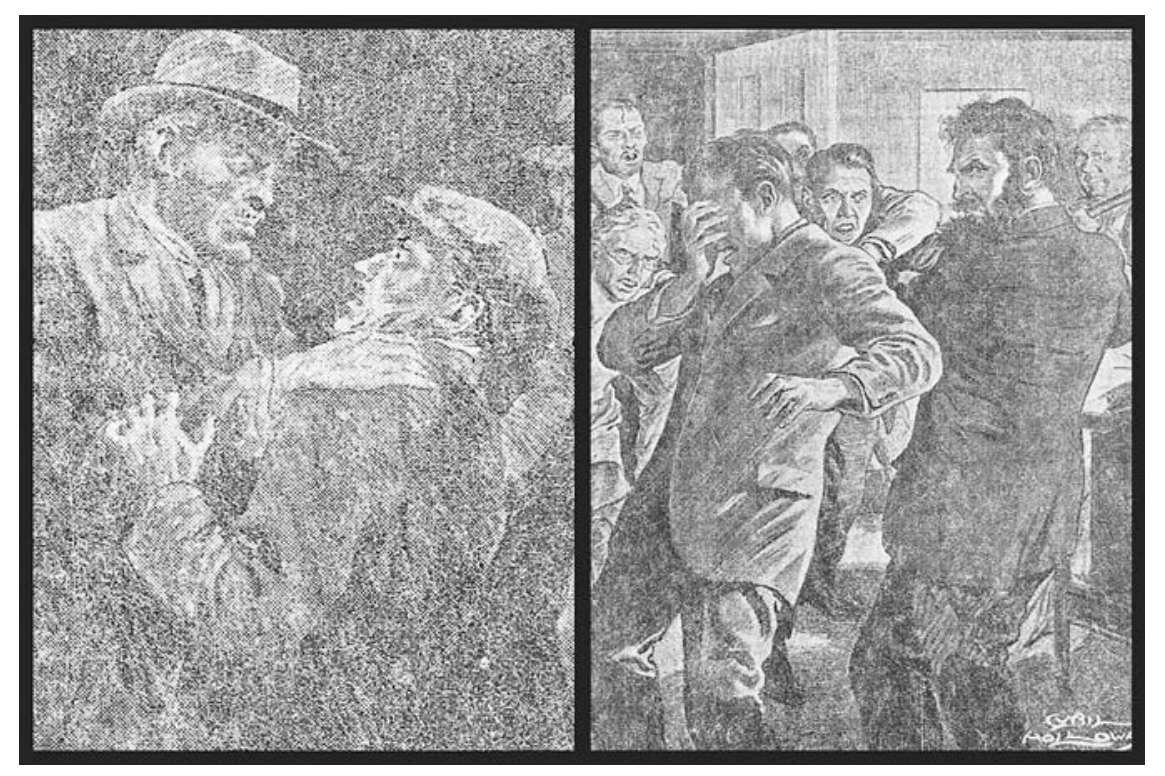

Figure 7. Illustrations from The Final Count published in Sovereign Magazine, October I925 and August I929. Left: "Drummond holding someone by the throat." Right: "In an instant he was helpless from the fumes, lurching and staggering about blindly."

Another sign of this never-ending conflict is the vocabulary used to portray the enemy. Describing interwar German politics, George Mosse suggests that language became "an instrument of brutalisation," resulting in "the dehumanisation of the enemy." ${ }^{6}$ In the Bulldog Drummond series, not only are antagonists compared to animals, they are also objectified and reduced to parasites that must be exterminated. Thus Drummond informs a villain that his gang "came into existence to exterminate things like you" (BG 253). Similarly, Drummond's friend Sir Bryan Johnstone dehumanizes the inner enemies by comparing them to "microbes" (BG $38 \mathrm{I})$. This dehumanization of the enemy, as well as the military organization of the Black Gang, has prompted many accusations of fascism. However, such allegations seem to have emerged only in hindsight after the Second World War, when private armies led by disenchanted officers appeared as a danger, not as a way to protect society against lawbreakers. But in his day Drummond was viewed, in Ion Trewin's phrase, as "simply an upstanding Tory who spoke for many of his countrymen." 77

If Drummond was not a fascist, he nevertheless exemplifies an ambiguous attitude to the law and to authority common among ex-soldiers. In The 
Long Week-End, Robert Graves and Alan Hodge wrote about the veterans' condescending attitude toward the Establishment. ${ }^{78}$ In his study of juvenile literature, Michael Paris also notes a "lack of respect for established authority and the tendency to anarchic behaviour" among interwar heroes.79 Hence Bulldog Drummond shows contempt for the police, who strike him as "unduly kind" to the conspirators (BG 2I4). Scotland Yard is generally presented as a bureaucratic organization, where "one filled in a form and waited" ( $\left.B D 7_{7}\right)$. Drummond wants no involvement with policemen, partly because his nocturnal activities place him on the wrong side of the law.

Far from being a "respectable citizen" $\left(B D 7_{78}\right)$, Drummond does not hesitate to break laws in order to punish lawbreakers. We are first introduced to his black gang as "a body of men who are not within law themselves," as Carl Peterson puts it ( $B G$ 2II). The gang risk "either prison or a knife in the back" ( $B G$ 267), risks also taken by their antagonists. Indeed, Drummond shows more respect for his archenemy Peterson than for the police. Not only is the cosmopolitan desperado able to hide his emotions, he is also a master of disguise. Peterson's qualities are similar to Drummond's: the same self-mastery, the same ability to surprise his prey. It is significant that Drummond labels Peterson "a foeman worthy of his steel" (TR 505-506), and compares their opposition to a boxing match between heavyweights. The titles The Third Round and The Final Count also refer to boxing, along with the "Four Rounds" added to the cover of the I 929 edition. Drummond is once again on the battlefield, in a fight unto death reminiscent of the combat between snipers portrayed in Shorty Bill, a one-on-one struggle between adversaries of extraordinary abilities.

In spite of their common themes with the war stories, the Bulldog Drummond novels were marketed as thrillers. A thriller features a crime, mystery, or espionage in an atmosphere of suspense and excitement. The Bulldog Drummond novels offered a British counterpoint to the American hard-boiled fiction that appeared after the First World War. Like Drummond, the typical hard-boiled detective is prone to brutality, disrespectful of authority, and ready to break the law to fight criminals. ${ }^{80}$ However, American hard-boiled fiction is usually set in derelict urban spaces, whereas the Bulldog Drummond novels feature country houses as well as upmarket London hotels. Moreover, Drummond does not share the social resentment so common among lowermiddle-class American detectives. As a wealthy gentleman, his criticism of the police and the law does not stem from a feeling of social injustice, but from a frustration at their supposed inefficiency. Besides a common brutality, what Drummond does share with American detective characters is disenchantment with postwar society, a society where veterans struggle to find a place. 
In spite of the Bulldog Drummond novels' continuities with the Great War, the marketing of these novels made very few allusions to the conflict. The dust wrappers and ads sell the books as thrillers. The cover of The Final Count, a novel dominated by the fear of universal destruction, pictures a giant spider instead of the weapon of mass destruction invented by Robin Gaunt (Figure 8). ${ }^{8 \mathrm{I}}$ Moreover, the dust jackets often picture Drummond as a handsome young man, dressed in a distinguished blue suit (Figure 9), whereas the ex-officer is characterized in the text by his "ugliness" and heavy body ( $B D$ I 5 ). In fact, Sapper often presents elegance as unmanly and incompatible with a soldier's life. Having met "an exquisite being arrayed in gorgeous apparel" at the Carlton Hotel, Drummond calls him a "priceless old stuffed tomato" (BD 85-86).

Not only did the dust jackets portray Bulldog Drummond as a civilian more than a soldier, the advertisements also sold an identifiable consumer product, set inside the definite limits of the thriller. A typical 1924 insert announced the publication of The Third Round, using the vocabulary of excitement: "amazing role," "the most exciting stories," "most thrilling books." This thriller label extended to the 1929 Bulldog Drummond movie, which was heralded as "the dynamic exploits of a daring adventurer" (Figure Io). Like the dust jackets, the poster pictures a good-looking Drummond, played by Ronald Colman.

Reflecting this rigid product identification, reviewers tended to present Sapper as a writer of thrillers, without any pretension to literary seriousness. The evolution is striking in the TLS, which had written during the war that Sapper could legitimately stake a claim to posterity. In contrast, the reviews of the Bulldog Drummond series highlight the characteristics of mass-market thrillers. ${ }^{82}$ The war is practically absent from this and other newspaper critiques. Reviewing The Black Gang, the Scotsman describes the "exciting situations" faced by Drummond and his friends, presented not as ex-officers but as "dare-devil youths." ${ }^{8} 3$ In sharp contrast, in I9I 6 the same newspaper hailed Men, Women, and Guns as a book that enabled "stay-at-home readers to realise something of the psychology of the men who occupy the fighting line." ${ }^{8}$ Sapper, who had once been portrayed as a realistic war writer, was now considered a mere entertainer.

The fact that Sapper apparently did not publish any articles in newspapers and serials during the I920s could have only reinforced his image as a lightweight. Although his novels were serialized in magazines such as Sovereign, he did not participate in the intellectual debates of his time. He was largely silent during the war books controversy in I929-I930, and the only trace of his opposition to disillusioned writers is the preface he wrote for the 


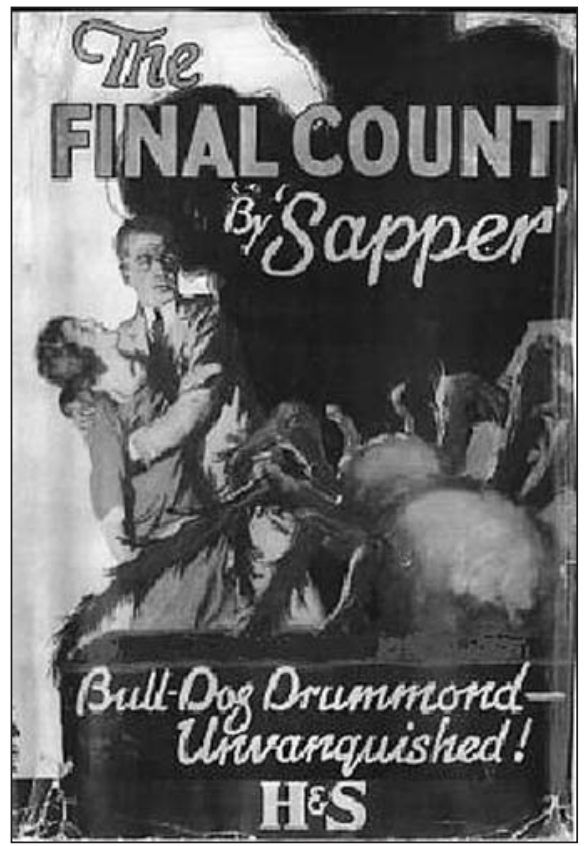

Figure 8. Dust jacket of The Final

Count, (Hodder \& Stoughton, I926).

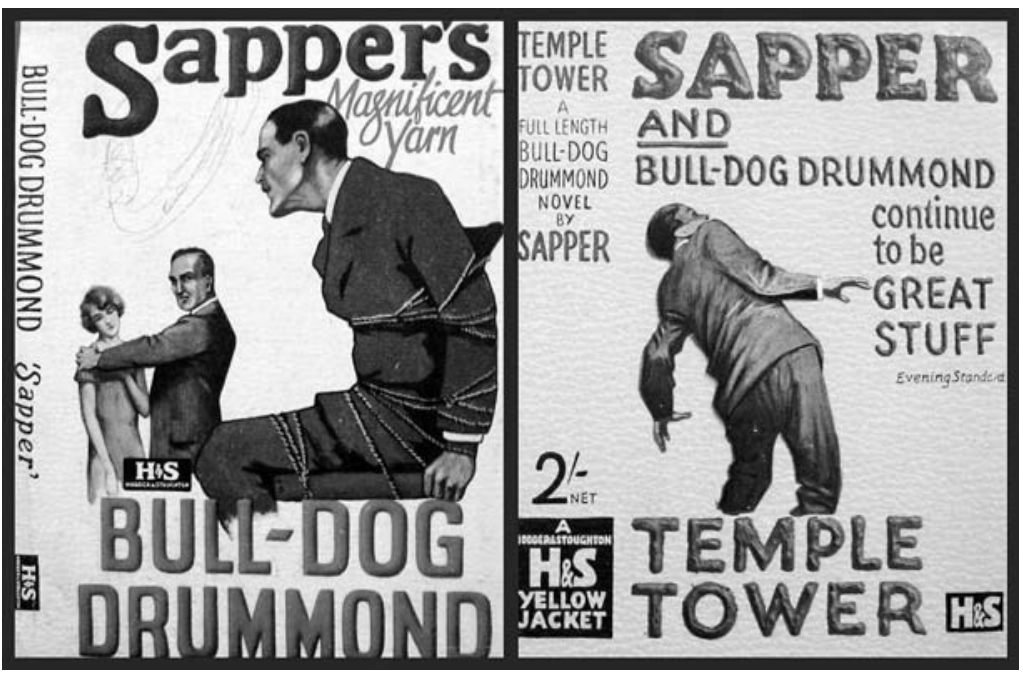

Figure 9. Dust jackets of Bulldog Drummond and Temple Tower (Hodder \& Stoughton, n.d.), Princeton University Library. 


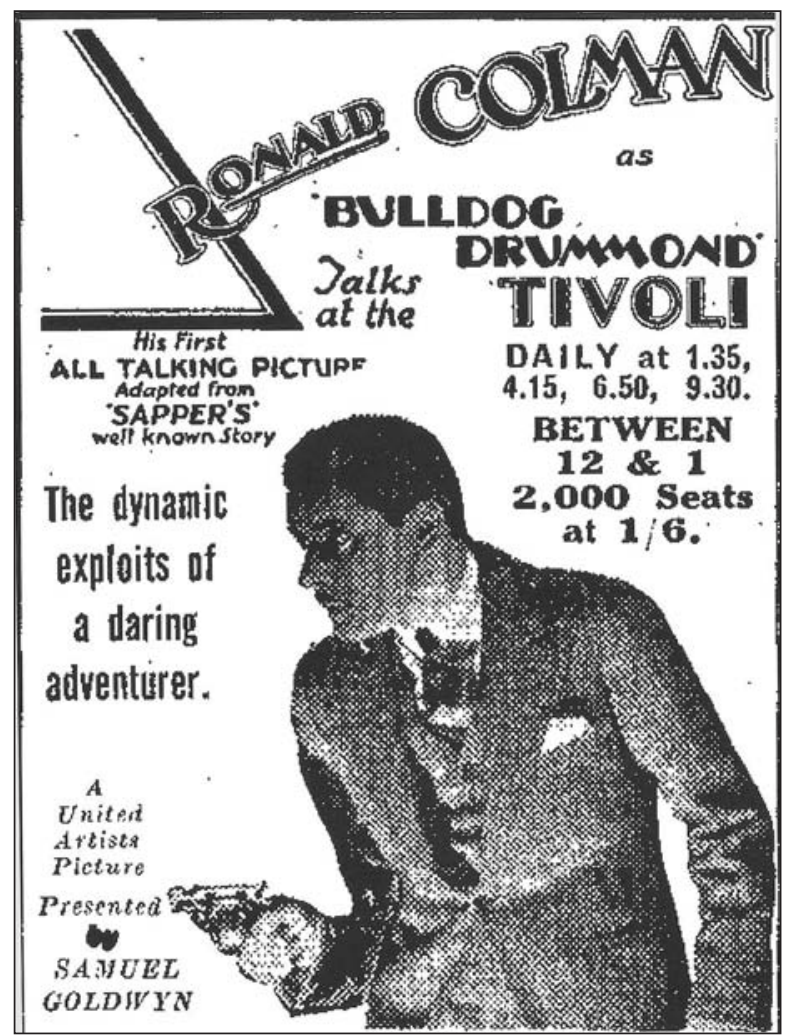

Figure Io. Advertisement for the Bulldog Drummond movie, Daily Mirror, June I7, I929.

I930 edition of his war stories. Military historians later rediscovered Cyril Falls and Charles Carrington, who had been more vocal in their opposition to the debunking war books.

Like Edgar Wallace, another successful writer of thrillers published by Hodder \& Stoughton, it could be argued that Sapper came to be "owned" by his publishers. ${ }^{85}$ Hodder \& Stoughton shaped Sapper's image through the way his novels were sold and promoted. In the first place, Sapper's writing had to fit the format of the Yellow Jacket series. Its success relied, as Milan Voykovic contends, on "saturating the market with novels that were instantly recognised and easy to read." ${ }^{86}$ After the success of his I 920 novel, Sapper exploited the Bulldog Drummond brand until his death in 1937. Hodder \& Stoughton certainly encouraged this choice, and continued to publish the Bulldog Drummond novels written by Gerard Fairlie after I937. 
In financial terms, this relationship between publisher and author was also mutually beneficial. Edgar Wallace once claimed, "Hodder pushed me up the ladder and Stoughton kept me at the top." ${ }^{{ }^{87}}$ Likewise, if Sapper started as an unknown young officer and died famous and wealthy, it was mainly due to his publisher's commercial strategy and aggressive advertising campaigns. Sapper's publishers sold his books at different prices to appeal to a wide range of consumers, as well as to extend the period of sales, with the most expensive editions issued first. The price tags of the Bulldog Drummond novels ranged from $9 \mathrm{~d}$ to $8 \mathrm{~s} 6 \mathrm{~d}$, but the Hodder \& Stoughton Profit and Loss Ledger shows that most consumers bought the 2 s editions. ${ }^{88}$ Cheap and compact, the 2 s was "easy to read" and "convenient to carry." ${ }^{89}$ This certainly contributed to Sapper's success, as did the excellent distribution of the Yellow Jacket series. According to David Glover, Hodder \& Stoughton made "particularly heavy use of W. H. Smith's growing chain of retail shops." $9 \circ$ And Sapper's publishers heavily invested on advertising. Whereas $£_{25}$ I had been allocated to the promotion of the first Bulldog Drummond novel between I92I and I925, the advertising budget for The Third Round reached $£_{477}$ between 1925 and $1929 .{ }^{91}$ These important advertising expenses are correlated to high sales. Figure in shows sales in the first five years after publication and the advertising budget in the same period. Only the four "Rounds" have been included. Of course, the Bulldog Drummond series continued to sell well after this five-year interval. The point of this graph is to highlight the growth in sales and advertising, from the first Bulldog Drummond novel to The Final Count. Sapper and his publishers managed to sustain the reader's interest, novel after novel.

With the help of his publisher and his agent, Sapper negotiated movie tie-ins and adapted his novels for the stage. Indeed, Sapper soon became less known than his "brand," Bulldog Drummond. ${ }^{92}$ When he died in 1937, the Daily Mirror focused on his success in the entertainment industry: "From the books, play and film built round Bulldog Drummond it is believed that he made a fortune of $£ 85,000 .{ }_{93}$ Sapper's reputation as a writer of mere entertainment still survives today. In the preface of a Bulldog Drummond reprint in 2007, David Stuart Davies contends that Sapper's narratives “are not deep or intellectual, but they are well-constructed adventure stories for grown-up boys or girls." ${ }^{94}$ This lowbrow label certainly explains why Sapper has attracted so little critical attention. As Kim Becnel argues, "as literary scholars, we remain invested in the cultural capital assigned to elite literature authored by those we have come to think of as 'true' artists." 95

Scholars tend to analyze writers retrospectively, without paying much attention to the ways they were perceived at different stages of their career. 


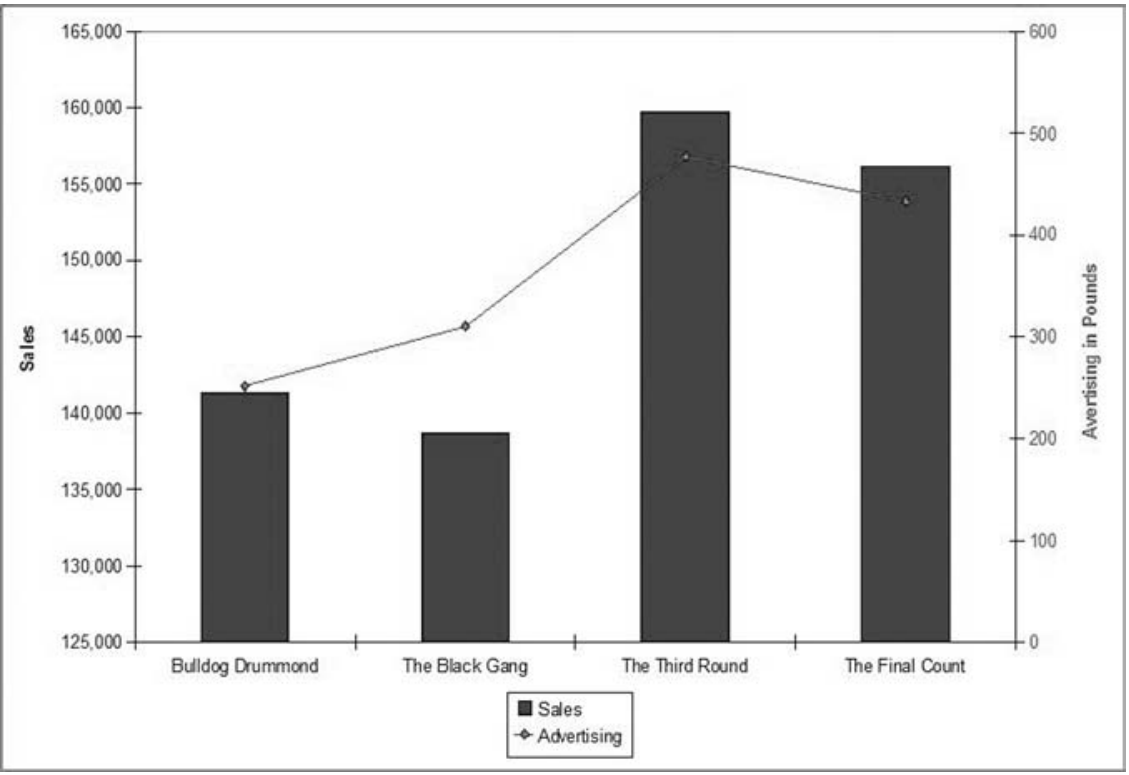

Figure II. Sales and advertising for the "Four Rounds" [Bulldog Drummond, I92I-I925; The Black Gang, I923-I927; The Third Round, I925-I929; The Final Count, I926-1930].

Had Sapper been published by Peter Davies (the distinguished publisher of Frederic Manning and Charles Carrington), we might have remembered him as a talented war writer-although his "nondisenchantment" would have kept him apart from Owen and Sassoon. In other words, we should not assume that texts we see as "lowbrow" had always been perceived as such. Moreover, Sapper's changing identity from "war writer" to "thriller writer" highlights the commercial purposes of these labels. Publishers used the label "war writer" as a marketing tool when the demand for war books was high. The failure of Sapper's Mufti and the perceived fall in the popularity of war books undoubtedly contributed to Hodder \& Stoughton's change of strategy. The marketing of the popular literature of the war provides important insights into the ways the conflict was interpreted, in the short and longer term.

\section{Notes}

I would like to thank Claire Feehily, Ion Trewin, and Milan Voykovic for their help during the research phase of this article. 
I. Examples include Siegfried Sassoon, Memoirs of a Fox-Hunting Man (London: Faber and Faber, I929); and Robert Graves, Good-bye to All That (London: Jonathan Cape, I929).

2. See Cyril Falls, War Books: A Critical Guide (London: Peter Davies, I930); and Douglas Jerrold, The Lie about the War: A Note on Some Contemporary War Books (London: Faber and Faber, 1930).

3. Sapper, War Stories (London: Hodder \& Stoughton, I930), 9 (hereafter cited as WS). Page numbers follow each title cited in parentheses in the text.

4. His correspondence with the Society of Authors, kept at the British Library, shows that the army shaped McNeile's social identity. In a letter dated November 27, I929, he is referred to as "Major McNeile" and is thanked for "the payment of $£_{5}$ annually to the Fighting Fund of the Society." Manuscript Collection, MS 63288.

5. Sapper, Bulldog Drummond [1920], in Bulldog Drummond: The Carl Peterson Quartet (London: Wordsworth, 2007), I4 (hereafter cited as $B D$ ).

6. The term "nondisillusioned" may be the most appropriate for the war writers who rejected bitterness and cynicism. As the historian Brian Bond contends, "it would be grossly unjust to label [them] 'pro-war,' and even 'patriotic' seems inadequate." Bond adds that "the distinction to be drawn is between those writers whose view of the First World War is negative (with 'futility' as their watchword), and those who stress its positive feature and legacy, despite full awareness of the destruction, suffering and heavy casualties." Brian Bond, "British 'AntiWar' Writers and Their Critics," in Facing Armageddon: The First World War Experienced, ed. Hugh Cecil and Peter Liddle (London: Leo Cooper, I996), 8 I 7.

7. See Bernard Bergonzi, Heroes' Twilight: A Study of the Literature of the Great War (London: Constable, I965); and Paul Fussell, The Great War and Modern Memory (Oxford: Oxford University Press, I975). Both Bergonzi and Fussell view the disenchanted narratives of Wilfred Owen, Siegfried Sassoon, and others as authentic representations of the war.

8. Richard Usborne, Clubland Heroes, 3rd ed. (London: Hutchinson, I983), I36, I48.

9. See Colin Watson, Snobbery with Violence: Crime Stories and Their Audience (London: Eyre \& Spottiswoode, I97I), 7I.

Io. Michael Denning, Cover Stories: Narrative and Ideology in the British Spy Thriller (London: Routledge, I987), 66.

II. John Onions, English Fiction and Drama of the Great War, I9I8-39 (London: Macmillan, I990), 34. Other critics have also presented Sapper as a propagandist. See, for instance, Jack Adrian, preface to Sapper, The Best Short Stories (London: Dent, I984), x.

I2. Samuel Hynes, A War Imagined: The First World War and English Culture (New York: Atheneum, I99I).

I3. Hugh Cecil, "British War Novelists," in Cecil and Liddle, Facing Armageddon, 803.

I4. Michael Paris, Warrior Nation: Images of War in British Popular Culture, I850-2000 (London: Reaktion Books, 2000).

I 5. Jessica Meyer, "The Tuition of Manhood: Sapper's War Stories and the Literature of the War," in Publishing in the First World War: Essays in Book History, ed. Mary Hammond and Shafquat Towheed (London: Macmillan, 2007), I 25.

16. Rosa Maria Bracco, Merchants of Hope: British Middlebrow Writers and the First World War, 1919-1939 (Providence, R.I.: Berg, I993).

I7. Meyer, "Tuition of Manhood," I I3.

I8. Ibid., I26.

19. Dan Todman, The Great War: Myth and Memory (London: Hambledon, 2005), xii. See also Gary Sheffield, Forgotten Victory: The First World War-Myths and Realities (London: Review, 2002).

20. The term "middlebrow," which refers to writers with a social/political message and a middle-class audience, appeared in the I920s and was popularized in the I930s.

2I. Several commentators suggest that Sapper also published his first short stories in Blackwood's Magazine. However, I have been unable to find any story by Sapper in the num- 
bers issued between I9I4 and I9I8. There may be a confusion with Ian Hay, who serialized The First Hundred Thousand in Blackwood's Magazine before it was published by Hodder \& Stoughton in I9I 5 .

22. Daily Mail, January I3, I9I 5, 4 (hereafter cited as DM).

23. John M. McEwan, "The National Press during the First World War: Ownership and Circulation," Journal of Contemporary History I7 (I982): 482.

24. J. Lee Thompson, Politicians, the Press and Propaganda: Lord Northcliffe and the Great War, I9I4-I9I9 (Kent, Ohio: Kent State University Press, I999), I 82.

25. "Sapper: Creator of Bulldog Drummond," Book and Magazine Collector, October I990, 25.

26. Jane Potter, "For Country, Conscience and Commerce: Publishers and Publishing, I9I4-18," in Hammond and Towheed, Publishing in the First World War, I6.

27. Imperial War Museum (London), Third Report on the Work Conducted for the Government at Wellington House, 6.

28. Herbert Strang, England and the War: A Book for Children (London: Henry Frowde and Hodder \& Stoughton, I9I6).

29. Hodder \& Stoughton had purchased a 25 percent share of Doran in 1908 . See George H. Doran, Chronicles of Barabbas, I884-I934 (London: Methuen, I935), 36.

30. The letters held at the New York Public Library highlight Sapper's close relationship with his agent, W. P. "Bill" Watt, whom he had met through the editor of the Daily Mail. New York Public Library, Berg Collection, Manuscripts Section, correspondence between Herman Cyril McNeile and A. P. Watt \& Son.

3I. Imperial War Museum, Second Report on the Work Conducted for the Government at Wellington House, 6. See also Gary S. Messinger, British Propaganda and the State in the First World War (Manchester: Manchester University Press, I992), 36.

32. For a list of authors agented by Watt, see University of North Carolina, Chapel Hill, Manuscripts Department, A. P. Watt Records.

33. For Buchan's role at Wellington House, see Kate Macdonald, "Translating Propaganda: John Buchan's Writing during the First World War," in Hammond and Towheed, Publishing in the First World War, I8. For Hay, see Peter Buitenhuis, The Great War of Words: Literature as Propaganda I 9I4-I8 and After (London: Batsford, I989), II 5.

34. The Guildhall Library (London), Hodder \& Stoughton Profit and Loss Ledger, Ms. I63 I 2, Vol. 39.

35. All amounts have been rounded off to the nearest pound. According to the publisher Stanley Unwin, an advertisement in a Sunday newspaper cost I $5 \mathrm{~s}$ per inch in I9I3. See Stanley Unwin, "The Advertising of Books," in Best Sellers: Are They Born or Made? ed. George Stevens and Stanley Unwin (London: Allen \& Unwin, I939), го.

36. All the sales figures are from the Hodder \& Stoughton Profit and Loss Ledger.

37. Publishers' Circular, January 3, I9I4, 7, January 5, I9I $8,8$.

38. John Attenborough, A Living Memory: Hodder and Stoughton Publishers, I8681975 (London: Hodder \& Stoughton, I975), 78.

39. DM, “Two Good War Books," June I2, I9I $5,4$.

40. DM, June 28, I9I 5, 4, June 29, I9I 5, 6, June 30, I9I 5.

4I. A. G. Cheverton, "Some Really Good Sellers," Publishers' Circular, December 9, I9I6, 629 .

42. http://greatwardustjackets.co.uk/page42.html (accessed June 6, 20I0).

43. [Francis Henry Gribble], "Men, Women, and Guns," TLS, September I 4, I9I6, 439.

44. DM, June I2, I9I 5,4 .

45. [Gribble], "Men, Women, and Guns," 439.

46. Review of Michael Cassidy, New York Times, August 27, I9I6.

47. Review of Men, Women, and Guns, Atlanta Constitution, November 26, I9I6.

48. Review of No Man's Land, Atlanta Constitution, October 7, I9I7. 
49. Review of No Man's Land, New York Times, October 7, I9I7.

50. Michael J. Birch, “The Popular Fiction Industry: Market, Formula, Ideology,” Journal of Popular Culture, 21, no. 3 (I987): 84.

5I. This slogan was originally taken from a review in Punch and later quoted in advertisements. For an example of a Hodder \& Stoughton advertisement featuring Sapper's slogan, see Daily Express, February 4, 1926.

52. Hynes, War Imagined, 48; Meyer, "Tuition of Manhood," I I 8-I I9.

53. DM, January 2I, I9I $5,4$.

54. Sapper, Sergeant Michael Cassidy R.E. (London: Hodder \& Stoughton, I9I 5), 38-39 (hereafter cited as $S M C$ ).

55. Sapper, The Lieutenant and Others (London: Hodder \& Stoughton, I9I 5), v (hereafter cited as $L O)$.

56. Hans Bertens, "A Society of Murderers Run on Sound Conservative Lines: The Life and Times of Sapper's Bulldog Drummond," in Twentieth-Century Suspense: The Thriller Comes of Age, ed. Clive Bloom (Basingstoke: Macmillan, I990), 5 I.

57. Many commentators suggest that Sapper's stories were read only by civilians. However, the stories were also aimed at soldiers, as the inclusion of "Ebeneezer the Goat" in the trench journal the Periscope shows (November I9I6: I4-I6). "Ebeneezer the Goat" had previously been published in The Lieutenant and Others.

58. DM, May 20, I9I 5,4 .

59. For a discussion on the supposed directness and transparency of diaries, see Ernst Van Alphen, Caught by History: Holocaust Effects in Contemporary Art, Literature, and Theory (Stanford, Calif.: Stanford University Press, I997), I I.

60. Similarly, The Lieutenant includes a scene where an officer fires on an unruly private, but the Daily Mail published an expurgated version. LO 50; DM, July 3, I9I $5,4$.

6I. Sapper, Men, Women, and Guns (London: Hodder \& Stoughton, I9I6), 27 (hereafter cited as $M W G)$.

62. See, for instance, $M W G 28 \mathrm{I}$.

63. $L O_{3} ; M W G$ I 5 .

64. For other examples of the transformative power of war, see Jane Potter, Boys in Khaki, Girls in Print: Women's Literary Responses to the Great War I9I4-I9I 8 (Oxford: Clarendon Press, 2005), II 2 and George Robb, British Culture and the First World War (London: Palgrave, 2002), I62.

65. C.N., The Making of an Officer (London: Hodder \& Stoughton, I9I6), 69, 67, 88. See also "Harvest" (WS I049): "From the tuition, which the manhood of Britain is now undergoing."

66. David Hodge, "Sapper," Bookman, July I9I9, I26-I27.

67. Review of Mufti, Punch, July 9, I919, 59.

68. http://greatwardustjackets.co.uk/page 42.html (accessed June 6, 20I0).

69. Bookman, December I922, I67.

70. For a list of Drummond's friends, see Ion Trewin, preface to Sapper, The Black Gang (London: Dent, I983), vii.

7I. See also Sapper, The Third Round [1924], in Bulldog Drummond: The Carl Peterson Quartet, 4I8 (hereafter cited as TR).

72. Esther MacCallum-Stewart, "The First World War and Popular Literature" (Ph.D. diss., University of Sussex, 2005), 40.

73. Sapper, Jim Brent (London: Hodder \& Stoughton, I926), 35.

74. TLS, "The Female of the Species," September I3, I928, 650.

75. Hynes, War Imagined, 356, 358.

76. George Mosse, Fallen Soldiers: Reshaping the Memory of the World Wars (New York:

Oxford University Press, I990), I70, I72.

77. Trewin, Black Gang, xi. 
78. Robert Graves and Alan Hodge, The Long Week-End: A Social History of Great Britain, 2nd ed. (London: Carcanet, 2006), I6.

79. Paris, Warrior Nation, I66.

80. George Grella, "Murder and the Means Streets: The Hard Boiled Detective Novel," in Detective Fiction: A Collection of Critical Essays, ed. Robin W. Winks (Englewood Cliffs, N.J.: Prentice-Hall, I980), I06.

8I. http://greatwardustjackets.co.uk/page42.html (accessed June 6, 2010).

82. For instance, [H. O. Lee], "Bull-Dog Drummond," TLS, August I2, I920, 5 I9.

83. Scotsman, September 25, I922, 7 .

84. Scotsman, September 7, I916, 2.

85. Birch, Popular Fiction Industry, 85.

86. Milan Voykovic, "The Culture of Thriller Fiction in Britain, I898-I945: Authors, Publishers and the First World War" (Ph.D. diss., University of New South Wales, I996), I35. 87. Cited in David Glover, "Looking for Edgar Wallace: The Author as Consumer," History Workshop Journal 37 (I994): I49.

88. See also Meyer, "Tuition of Manhood," I23. For instance, by 1939 The Black Gang had sold 20,938 copies at $7 \mathrm{~s} 6 \mathrm{~d}$ and $\mathrm{I} 67, \mathrm{I} 28$ copies at $2 \mathrm{~s}$.

89. Voykovic, "Culture of Thriller Fiction," I 66.

90. Glover, "Looking for Edgar Wallace," I 49.

9I. All figures have been rounded off to the nearest pound.

92. The comparison with Ian Fleming and his character James Bond is an obvious one. According to John Attenborough, "both authors thought of their heroes in the same commercial terms." Attenborough, Living Memory, roo.

93. Daily Mirror, "Sapper's Books Made $£ 85,000$," August I6, I937. McNeile left at his death an estate worth nearly $£_{26,167}$. See Jonathon Green, "McNeile, (Herman) Cyril (I888-I937)", Oxford Dictionary of National Biography, Oxford University Press, 2004, http://www.oxforddnb.com/view/article/348Io (accessed Feb 7, 20I I)

94. David Stuart Davies, preface to Bulldog Drummond: The Carl Peterson Quartet, xiii.

95. Kim Becnel, The Rise of Corporate Publishing and Its Effects on Authorship in Early Twentieth-Century America (New York: Routledge, 2008), 3. 